\title{
Results of Favipiravir Combined Treatment in Intensive Care Patients with COVID-19
}

\section{COVID-19 Tanılı Yoğun Bakım Hastalarında Favipiravir Kombine Tedavisinin Sonuçları}

\section{(D) Habip Yılmaz1, (D) Abdullah Emre Güner1', (D) Murat Altuntaş2}

1İstanbul Provincial Health Directorate, İstanbul, Turkey

${ }^{2}$ University of Health Sciences Turkey, İstanbul Bağcllar Training and Research Hospital, Clinic of Family Medicine, İstanbul, Turkey

\section{Abstract}

Objective: Coronavirus disease-2019 (COVID-19) is a disease that has already taken place in human history. Although there is still no effective treatment protocol, different treatment options are being tried. In this study, it was aimed to determine the basic characteristics and changes in laboratory findings of patients who were hospitalized with the diagnosis of COVID-19 in the intensive care unit and underwent treatment protocol containing favipiravir.

Method: It was carried out with the data of 179 inpatients in an intensive care unit between 01.06 .2020 and 30.06 .2020 . The inclusion criteria of the study were to have a diagnosis of COVID-19 confirmed by polymerase chain reaction test, to be hospitalized in the intensive care unit, to be receiving therapy combined with favipravir and to have access to its data through the automation system. According to literature, the sociodemographic characteristics, some basic characteristics and some laboratory findings of the patients were evaluated. Statistical analyses were performed using the Statistical Package for Social Sciences (SPSS) version 24.0 (IBM Corp.; Armonk, NY, USA).

Results: The average age of the study group was $60.9 \pm 16.4$ years and $65.9 \%(n=118)$ of them were male. According to the clinical classification, more than half $(50.8 \%, n=91)$ were included in the "high" clinical classification. The most common chronic disease was "hypertension (HT)" (42.5\%, n=76) and the most common symptom was "fever" (57.5\%, $n=103)$. While $82.7 \% \quad(n=148)$ had widespread computed tomography findings, C-reactive protein (CPR) positivity rate was $65.4 \%$ $(n=117)$. Statistically significant difference was detected among three measurements of blood urea nitrogen, aspartate aminotransferase, alanine aminotransferase, CRP between during admisson, the $1^{\text {st }}$ and the $3^{\text {rd }}$ days.

\section{Öz}

Amaç: Koronavirüs hastalığı-2019 (COVID-19) insanlık tarihinde çoktan yerini almış bir hastalıktır. Halen etkili bir tedavi protokolü bulunmamakla birlikte farklı tedavi seçenekleri denenmektedir. Bu çalışmada yoğun bakım ünitesine COVID-19 tanısıyla yatırılan ve favipiravir içeren tedavi protokolü uygulanan hastaların temel özelliklerinin ve laboratuvar bulgularındaki değişikliklerin belirlenmesi amaçlanmıştır.

Yöntem: Çalışma 01.06.2020-30.06.2020 tarihleri arasında yoğun bakım ünitesinde yatan 179 hastanın verileriyle gerçekleştirilmiştir. Çalışmaya dahil edilme kriterleri; polimeraz zincir reaksiyon testi ile doğrulanmış COVID-19 tanısına sahip olmak, yoğun bakım ünitesinde yatırımak, favipiravir ile kombine tedavi almak ve otomasyon sistemi üzerinden verilerine erişilebilmektir. Literatüre göre hastaların sosyodemografik özellikleri, bazı temel özellikleri ve bazı laboratuvar bulguları değerlendirilmiştir. İstatistiksel analiz SPSS (Statistical Package for Social Sciences) versiyon 24.0 (IBM Corp.; Armonk,NY,ABD) kullanılarak yapılmıştır.

Bulgular: Çalışma grubunun yaş ortalaması $60,9 \pm 16,4$ yıl olup, \%65,9'u $(n=18)$ erkektir. Klinik sınıflandırmaya göre yarıdan fazlası $(\% 50,8, n=76)$ "yüksek" klinik sınıflandırmaya dahil edilmiştir. En sık görülen kronik hastalık "hipertansiyon" (\%42,5, $n=76)$ ve en sı görülen semptom "ateş"tir (\%57,5, $n=103)$. \%82,7'sinde ( $n=148$ ) yaygın bilgisayarlı tomografi bulguları bulunurken, C-reaktif protein (CPR) pozitiflik oranı \%65,4'tür ( $n=117)$. Başvuru sırasında, birinci ve üçüncü günler arasında üç kan üre nitrojen, aspartat aminotransferaz, alanin aminotransferaz, CRP ölçümleri arasında istatistiksel olarak anlamlı bir fark tespit edilmiştir.

Sonuç: Favipiravir uygun bir güvenlik profili göstermektedir. Ancak yan etkileri, teratojenitesi, hiperürisemi ve düzeltilmiş QT aralığı uzaması

Address for Correspondence: Habip Yılmaz, İstanbul Provincial Health Directorate, İstanbul, Turkey

E-mail: dr.habipyilmaz@hotmail.com ORCID: orcid.org/0000-0002-5138-3940 Received: 09.07.2021 Accepted: 01.09.2021

Cite this article as: YIImaz H, Güner AE, Altuntaş M. Results of Favipiravir Combined Treatment in Intensive Care Patients with COVID-19. Bagcilar Med Bull 2021;6(3):339-345

๑ $C$ Copyright 2021 by the Health Sciences University Turkey, Bagcilar Training and Research Hospital Bagcilar Medical Bulletin published by Galenos Publishing House. 


\section{Abstract}

Conclusion:Favipiravir demonstrates a proper safety profile. However, its side effects including teratogenicity, hyperuricemia and QTc (corrected QT interval) prolongation have not yet been adequately studied. It may be safe and tolerable in short-term use, but more evidence is needed to assess the longer-term effects of treatment.

Keywords: COVID-19, favipiravir, laboratory findings, side effect, treatment

\section{Öz}

henüz yeterince araştırılmamıştır. Kısa süreli kullanımda güvenli ve tolere edilebilir olabilir; ancak tedavinin uzun dönem etkilerini değerlendirmek için daha fazla kanıt gerekmektedir.

Anahtar kelimeler: COVID-19, favipiravir, laboratuvar bulguları, tedavi, yan etkiler

\section{Introduction}

In the twenty first century, three new life-threatening diseases caused by coronavirus emerged. These are Middle East respiratory syndrome (MERS), severe acute respiratory syndrome (SARS) and the new lung disease Coronavirus disease-2019 (COVID-19) (1). All of them belong to the Coronaviridae family; kind of viruses that possess a positivesense single-stranded RNA genome. Similar to other RNA viruses, this family is characterized by significant genetic variability and high recombination rate that enable them distributed easily among humans and animals worldwide (2). COVID-19 appeared in Wuhan, China in December 2019. It is a disease caused by the 2019 novel Coronavirus (2019-nCoV) that manifests itself with viral pneumonia in most patients (3). Due to its high infectivity and fatality rate, also the absence of specific medicine for 2019-nCoV, outbreak of the disease has brought heavy burden to the world.

Symptoms in COVID-19 may range from mild illness to acute respiratory distress syndrome. The common characteristics of people with severe disease are showing lymphocytopenia, being old and smoking (4). In addition, in a meta-analysis consisting of 15 studies, it was stated that severe disease was associated with an underlying hypertension (HT), diabetes, and a respiratory or cardiac pathology (5).

So far, there is no treatment protocol and vaccination for COVID-19 with proven safety and efficacy. Today, the main treatments are shaped according to our experiences with similar viruses such as SARS-Cov and MERS-Cov (3). In addition to symptomatic treatments, different treatment methods such as remdesivir, chloroquine and hydroxychloroquine, kaletra, favipiravir, tocilizumab, and stem cell therapy are used $(6,7)$. As the virus causes endothelial dysfunction, procoagulant conditions and renin-angiotensin-aldosterone system imbalance, use of low molecular weight heparin, low dose aspirin, angiotensin converting enzyme inhibitor or angiotensin II receptor blocker in the early period is also recommended (8). Despite all these, there is currently no effective treatment available for coronavirus infections. Hard works have been made to develop vaccines and therapeutic drugs. Preclinical evidence has proven the potential of several countermeasures, yet large scale trials are still needed (2).

Favipiravir, one of the mentioned treatment methods, is a kind of RNA-dependent RNA polymerase inhibitor, blocking RNA virus replication. It is a potential antiviral agent used against SARS-CoV-2 (9). Favipiravir is active against a variety of influenza viruses including A (H1N1) pdm09, A (H5N1) and A (H7N9) avian influenza viruses and has a synergistic effect with oseltamivir (10). It is an approved treatment for influenza. Besides, less studies have been published for favipiravir to treat SARS-CoV-2 compared to remdesivir. Indeed, favipiravir was approved by the National Medical Products Administration of China as the first anti-COVID-19 drug in March 2020, as the clinical trial had demonstrated efficacy with minimal side effects (2). It accelerates clinical recovery by reducing respiratory problems (3). The effective dose of favipiravir used is $1.600 \mathrm{mg}$ twice daily (first day), $600 \mathrm{mg}$ twice daily (days 2-5) and it is not used more than 14 days. However, favipiravir is contraindicated in pregnant women because of teratogenicity and embryotoxicity in animals $(10,11)$. Since the effectiveness and tolerability of hydroxychloroquine in treatment contain some question marks, recently, researchers have started to work mostly on remdesivir and favipiravir (8). In contrast to remdesivir, the studies on favipiravir in vitro and in vivo are limited. However, there are still three active clinical trials regarding favipiravir that have begun enrolling patients in China (12).

The COVID-19 pandemic stands as a serious health threat to humanity. The data obtained show that the treatment approaches applied especially for patients, who are being treated during the intensive care period, can make serious differences on prognosis. In this study, it was aimed to determine the basic characteristics and changes in laboratory findings of patients who were hospitalized with 
the diagnosis of COVID-19 in the intensive care unit of a training and research hospital and underwent treatment protocol containing favipiravir.

\section{Materials and Methods}

The study was planned in a retrospective, cross-sectional way. It was carried out with the data of inpatients at the University of Health Sciences Turkey, İstanbul Göztepe Training and Research Hospital Adult Intensive Care Unit between 01.06.2020 and 30.06.2020. The study was approved by the Ethics Committee of University of Health Sciences Turkey, İstanbul Göztepe Training and Research Hospital, Turkey with the decision number 2020/0243. In addition, TR Ministry of Health Scientific Research Platform on COVID-19 has also obtained a work permit with the date 05.09.2020 and number T175416.

The inclusion criteria of the study are to have a diagnosis of COVID-19 confirmed by polymerase chain reaction (PCR) test, to be hospitalized in the intensive care unit, to be receiving favipiravir combined therapy and to have access to its data through the automation system. The study included data from 179 patients who met these criteria.

According to literature, the socio-demographic characteristics, some basic characteristics and some laboratory findings of the patients were obtained from the hospital computer records. Clinical status of the patients were classified as mild, moderate and high.

\section{Statistical Analysis}

Statistical analyses were performed using the Statistical Package for Social Sciences version 24.0 (IBM Corp.; Armonk, NY, USA). Means and standard deviations are given for the variables obtained by measurement, number and percentage distributions for the data obtained by counting. The Friedman test in non-parametric conditions and ANOVA (repeated measure) test for repeated measurements in parametric conditions were used in comparison of admission, $1^{\text {st }}$ day and $3^{\text {rd }}$ day values of laboratory examination results. Statistical significance level was accepted as $p<0.05$ considering the $95 \%$ confidence interval and 5\% margin of error.

The Shapiro-Wilk test was used to adapt to normal distribution in the evaluation of parametric conditions. It was observed that BUN and procalcitonin $3^{\text {rd }}$ day values did not comply with the normal distribution $(\mathrm{p}<0.05)$. Therefore, the Friedman test, which is a non-parametric test, was used in the analysis of these values. The ANOVA (repeated measure) test was used for repeated measurements, as the others conformed to the normal distribution. While evaluating the test results, Wilks' lambda p-value was taken into consideration when $\mathrm{p}<0.05$ according to Mauchly Sphericity test.

\section{Results}

One hundred seventy nine patients were included in the study. The average age of the study group was $60.9 \pm 16.4$ years and $65.9 \%(n=118)$ of them were male. According to the clinical classification, more than half $(50.8 \%, \mathrm{n}=91)$ were included in the "high" clinical classification. The most common chronic disease was "HT" $(42.5 \%, \mathrm{n}=76)$ and the most common symptom was "fever" ( $57.5 \%, \mathrm{n}=103)$. While 82.7\% ( $\mathrm{n}=148)$ had widespread computed tomography findings, PCR positivity rate was $65.4 \%(\mathrm{n}=117)$. The main characteristics of the patients are summarized in the table below (Table 1).

Table 1. Basic characteristics of the patients

Group with favipiravir in the treatment regimen $(n=179)$

\begin{tabular}{|c|c|}
\hline \multicolumn{2}{|l|}{ Gender $\mathbf{n}(\%)$} \\
\hline Female & $61(34.1)$ \\
\hline Male & $118(65.9)$ \\
\hline \multicolumn{2}{|l|}{ Age n (\%) } \\
\hline$<65$ & $107(59.8)$ \\
\hline$\geq 65$ & $72(40.2)$ \\
\hline \multicolumn{2}{|l|}{ Clinical classification n (\%) } \\
\hline Mild & $1(0.6)$ \\
\hline Moderate & $87(48.6)$ \\
\hline High & $91(50.8)$ \\
\hline Hypertension n (\%) & $76(42.5)$ \\
\hline Diabetes mellitus n (\%) & $52(29.1)$ \\
\hline $\begin{array}{l}\text { Chronic obst. pul. disease } n \\
(\%)\end{array}$ & $15(8.4)$ \\
\hline Asthma n (\%) & $9(5.0)$ \\
\hline Hearth disease $n(\%)$ & $42(23.5)$ \\
\hline Cancer n (\%) & $5(2.8)$ \\
\hline \multicolumn{2}{|l|}{ Symptoms n (\%) } \\
\hline Fever & $103(57.5)$ \\
\hline Dyspnea & $76(42.5)$ \\
\hline Runny nose & $4(2.2)$ \\
\hline Pneumonia n (\%) & $175(97.8)$ \\
\hline \multicolumn{2}{|l|}{ Tomography findings $\mathrm{n}(\%)$} \\
\hline Local & $22(12.3)$ \\
\hline Common & $148(82.7)$ \\
\hline No evidence & $9(5.1)$ \\
\hline PCR positivity n (\%) & $117(65.4)$ \\
\hline
\end{tabular}

PCR: Polymerase chain reaction 
Laboratory measurements were carried out on adimission to the intensive care hospitalization, on the $1^{\text {st }}$ day and on the $3^{\text {rd }}$ day.

The values of all patients who were admitted to the intensive care unit (ICU) and treated with favipiravir/ favipiravir + tosilizumab given in Table 2 . They were compared on the day of admission to the intensive care unit and $1^{\text {st }}$ and $3^{\text {rd }}$ days days of hospitalization and statistically significant difference was found for BUN $(\mathrm{p}=0.000)$, AST $(\mathrm{p}=0.029)$, ALT $(\mathrm{p}=0.001)$, CRP $(\mathrm{p}=0.001)$, ferritin $(\mathrm{p}=0.024)$ and $\mathrm{D}$-dimer $(\mathrm{p}=0.000)$ (Table 2$)$.

AST, ALT and D-dimer values increased in a statistically significant way in patients receiving favipiravir/favipiravir + tosilizumab treatment. It was seen that CRP and ferritin values increased on the $1^{\text {st }}$ day and decreased on the $3^{\text {rd }}$ day (Table 2).

The values of the patients treated with only favipiravir were given in Table 3. The BUN, ALT, CRP and D-dimer values of patients who were admitted to ICU and treated with favipiravir were compared on the day of admisson, day 1 and day 3 and a statistically significant difference was found for BUN $(p=0.000)$, ALT $(p=0.000)$, CRP $(\mathrm{p}=0.000)$ and $\mathrm{D}$-dimer $(\mathrm{p}=0.000)]$. ALT and $\mathrm{D}$-dimer values increased significantly while CRP value increased on day 1 and decreased on day 3 (Table 3 ).

The values of the patients treated with favipiravir/ tocilizumab combination were given in Table 4. Creatinine, ALT, CRP, ferritin and D-dimer values were compared on the admission, and days 0 and 3 of hospitalization in patients who were admitted to ICU and treated with combination of favipiravir and tocilizumab, and a statistically significant difference was found for creatinine $(\mathrm{p}=0.000)$, ALT $(\mathrm{p}=0.03)$, CRP $(\mathrm{p}=0.004)$, ferritin $(\mathrm{p}=0.03)$ and $\mathrm{D}$-dimer $(\mathrm{p}=0.01)$. ALT and ferritin values increased significantly while CRP and D-dimer increased on day 1 and decreased on day 3 (Table 4).

\section{Discussion}

In Japan, favipiravir was approved as a stockpile against influenza pandemics and was distributed as an option against for SARS-CoV-2 under government control. Still, the efficacies of antiviral therapies have not been clarified clearly in the course of these patients. However, in the literature, there is a case report that emphasizes recovery two days after favipiravir treatment. This case suggests that favipiravir may be contributed to the amelioration of the lung lesion in COVID-19 (13).

In a large scale study, among the 1.023 deaths, the majority were among patients of $\geq 60$ years of age. The $\geq 80$ age group was characterized by the highest fatality rate (20.3\%) among all age groups (14). Relatively fewer cases were reported among young children ( 0 -9 yearsold). While more males were affected by the disease, the male-to-female ratio varied between different populations. As the pathogen has been extraordinarily contagious, no deaths have occurred in mild or even severe cases; but the fatality rate reached $49 \%$ among patients that were classified as critical cases (14). These findings are compatible with the present study.

\begin{tabular}{|c|c|c|c|c|c|c|c|}
\hline $\begin{array}{l}\text { Laboratory } \\
\text { findings }\end{array}$ & Day 0 & Day 1 & Day 3 & p & Days 0/1 & Days $0 / 3$ & Days 1/3 \\
\hline Lymphocyte & $1.29 \pm 0.93$ & $1.19 \pm 0.84$ & $1.22 \pm 0.78$ & 0.590 & 0.203 & 0.858 & 0.433 \\
\hline BUN & $42.96 \pm 28.77$ & $42.07 \pm 33.24$ & $42.71 \pm 36.87$ & 0.000 & 0.006 & 0.095 & 0.682 \\
\hline AST & $47.51 \pm 151.69$ & $57.97 \pm 255.23$ & $63.19 \pm 167.83$ & 0.029 & 0.015 & 0.020 & 0.199 \\
\hline ALT & $38.51 \pm 47.49$ & $43.4 \pm 63.79$ & $69.41 \pm 17197$ & 0.001 & 0.081 & 0.000 & 0.000 \\
\hline CRP & $81.02 \pm 74.86$ & $114.9 \pm 78.21$ & $89.81 \pm 79.5$ & 0.001 & 0.000 & 0.269 & 0.000 \\
\hline Procalcitonin & $1.18 \pm 3.09$ & $2.12 \pm 9.12$ & $2.77 \pm 11.36$ & 0.099 & 0.030 & 0.388 & 0.059 \\
\hline Ferritin & $1049.46 \pm 3642.29$ & $1227.22 \pm 3574.8$ & $1177.04 \pm 3108.04$ & 0.024 & 0.000 & 0.001 & 0.449 \\
\hline
\end{tabular}

*Hosp. means hospitalization, CRP: C-reactive proetin, BUN: Blood urea nitrogen, AST: Aspartate aminotransferase, ALT: Alanine aminotransferase 
A prospective, multicenter, open-label, randomized superiority trial examined the efficacy of favipiravir versus arbidol for treating COVID-19 (15). There was no difference in the 7-day clinical recovery rate for favipiravir versus arbidol in the overall population. However, this difference existed for a subgroup of non-critical patients without HT or diabetes (15). Three registered clinical trials are planned regarding the use of favipiravir against COVID-19 (16-18). The presented study was performed in an intensive care unit and parallel to the mentioned studies; $42.5 \%$ of the patients $(n=76)$ had HT and $29.1 \%(n=52)$ had diabetes mellitus.

In the present study, the most common symptom was "fever" (57.5\%, $\mathrm{n}=103)$ and second symptom was dyspnea
(42.5\%, $\mathrm{n}=76)$. In a similar study, the major symptom at the onset of illness was again fever (88.7\%) (5). The other symptoms were cough $(67.8 \%)$, fatigue $(38.1 \%)$, dyspnea (18.7\%), and myalgia (14.9\%). Additionally, these symptoms could be followed by sputum production, dizziness, headache, vomiting, abdominal pain, diarrhea, sore throat, nasal congestion and rhinorrhea (5). Differently, in a small study, two patients reported diarrhea, one had liver injury and one had poor diet (19). The recent study from China reported favipiravir had fewer side effects such as diarrhea and transaminitis in non-transplant COVID-19 (20).

There are some studies about the heart related disorders during medical treatment combined with favipravir. A

Table 3. Comparison of the laboratory findings of favipiravir treatment in hospitalized patients on admission, day 1 and day 3 , in intensive care unit

\begin{tabular}{|c|c|c|c|c|c|c|c|}
\hline Laboratory findings & Day 0 & Day 1 & Day 3 & $\mathbf{p}$ & Days $0 / 1$ & Days $0 / 3$ & Days $1 / 3$ \\
\hline Leukocyte & $7.8 \pm 4.22$ & $7.89 \pm 4.01$ & $8.12 \pm 4.1$ & 0.27 & 0.48 & 0.11 & 0.13 \\
\hline Lymphocyte & $1.31 \pm 0.95$ & $1.2 \pm 0.87$ & $1.25 \pm 0.79$ & 0.39 & 0.10 & 0.68 & 0.23 \\
\hline Creatinine & $1.35 \pm 1.21$ & $1.37 \pm 1.41$ & $1.36 \pm 1.06$ & 0.37 & 0.04 & 0.84 & 0.45 \\
\hline AST & $49.67 \pm 163.89$ & $61.12 \pm 275.89$ & $63.29 \pm 181.04$ & 0.23 & 0.04 & 0.19 & 0.60 \\
\hline Procalcitonin & $0.81 \pm 1.79$ & $2.28 \pm 9.97$ & $3.29 \pm 12.65$ & 0.20 & 0.06 & 0.27 & 0.02 \\
\hline Ferritin & $1088.98 \pm 3916.67$ & $1236.21 \pm 3849.44$ & $1169.39 \pm 3345.06$ & 0.10 & 0.00 & 0.02 & 0.66 \\
\hline D-dimer & $1374.14 \pm 2774.97$ & $1822.96 \pm 3204.11$ & $2035.12 \pm 3405.97$ & 0.00 & 0.06 & 0.00 & 0.02 \\
\hline $\mathrm{Fi}-\mathrm{O}_{2}$ & $45.73 \pm 29.09$ & $53.28 \pm 26.55$ & $55.31 \pm 28.13$ & 0.79 & 0.40 & 0.33 & 0.68 \\
\hline
\end{tabular}

*Hosp, means hospitalization, CRP: C-reactive proetin, BUN: Blood urea nitrogen, AST: Aspartate aminotransferase, ALT: Alanine aminotransferase

Table 4. Comparison of laboratory findings on admission and days 1 and 3 of hospitalization in intensive care patients who received favipiravir and tosilizumab treatment together

\begin{tabular}{lllllccc}
$\begin{array}{l}\text { Laboratory } \\
\text { findings }\end{array}$ & Day $\mathbf{0}$ & Day $\mathbf{1}$ & Day $\mathbf{3}$ & $\mathbf{p}$ & Days $\mathbf{0 / 1}$ & Days $\mathbf{0 / 3}$ & Days $\mathbf{1 / 3}$ \\
Leukocyte & $9.64 \pm 4.46$ & $10.71 \pm 5.89$ & $10.41 \pm 5.98$ & 0.59 & 0.360 & 0.465 & 0.897 \\
Lymphocyte & $1.17 \pm 0.73$ & $1.29 \pm 0.69$ & $1.12 \pm 0.7$ & 0.61 & 0.505 & 0.623 & 0317 \\
BUN & $37.71 \pm 15.68$ & $38.06 \pm 16.78$ & $38.29 \pm 19.62$ & 0.98 & 0.783 & 0.906 & 0.653 \\
Creatinine & $1.21 \pm 0.33$ & $1.06 \pm 0.24$ & $1 \pm 0$ & 0.00 & 0.018 & 0.012 & 0.317 \\
AST & $40.06 \pm 17.94$ & $49.29 \pm 25.32$ & $70.06 \pm 54.12$ & 0.00 & 0.099 & 0.002 & 0.058 \\
ALT & $43.06 \pm 19.13$ & $60.47 \pm 41.65$ & $76.88 \pm 40.66$ & 0.03 & 0.019 & 0.003 & 0.193 \\
CRP & $96.07 \pm 89.2$ & $161.24 \pm 94.3$ & $144.12 \pm 95.35$ & 0.01 & 0.004 & 0.028 & 0.523 \\
Procalcitonin & $2.67 \pm 7.01$ & $1 \pm 2$ & $0.64 \pm 1.34$ & 0.43 & 0.225 & 0.893 & 0.317 \\
Ferritin & $1121.31 \pm 1220.96$ & $1499.67 \pm 1120.54$ & $1551.25 \pm 1524.33$ & 0.03 & 0.310 & 0.038 & 0.331 \\
D-dimer & $840.21 \pm 724.47$ & $4877.38 \pm 9598.96$ & $4230.18 \pm 5685.62$ & 0.01 & 0.017 & 0.003 & 0.679 \\
Fi-O 2 & $40.5 \pm 27.58$ & $71.25 \pm 8.54$ & $62.5 \pm 9.57$ & 0.36 & 0.317 & 0.542 & 0.180 \\
Pa-O & $67 \pm 0$ & $51.75 \pm 21.79$ & $69 \pm 13.78$ & 0.37 & 0.572 & 0.624 & 0.068 \\
\hline
\end{tabular}

*Hosp. means hospitalization, CRP: C-reactive proetin, BUN: Blood urea nitrogen, AST: Aspartate aminotransferase, ALT: Alanine aminotransferase 
study that reports prolonged QT interval due to favipiravir has been encountered (19). In another study, two patients who were followed up in the ICU with favipiravir combined treatment developed ventricular tachycardia; both had increased $\mathrm{T}$ peak to $\mathrm{T}$ end (Tp-e) interval and Tp-e/ corrected QT interval (QTc) ratio despite normal QTc intervals before the treatment (21). In the present study $23.5 \%(n=42)$ of the patients had heart disease during the hospitalization but no heart related problem was detected during follow-up.

In the presented study, no significant adverse reactions were noted related to favipiravir or favipiravir/ticilizumab combined treatment group. In another study, favipiravir had significantly fewer adverse effects than the lopinavir/ ritonavir group (22). Similarly, a trial conducted on patients with COVID-19 indicated better results in patients treated with favipiravir than the group treated with lopinavir/ ritonavir. Additionally, less side effects were noted in the treatment group (20).

Studies have reported that lymphocytopenia occurs in severe types of COVID-19 (23). Again, lymphocytopenia and hyponatremia were detected in a patient who recovered after treatment for COVID-19 pneumonia (24). In a Japanese clinical trial with 501 patients, the main adverse reactions were detected as rising uric acid ( $\mathrm{n}=24,4.79 \%)$, diarrhea $(n=24,4.79 \%)$, neutropenia $(n=9,1.80 \%)$, increased AST $(n=9,1.80 \%)$ and increased ALT $(n=8,1.60 \%)(25)$. In a trial of favipiravir with patients with COVID-19, the most common adverse events were liver enzyme abnormalities, psychiatric, gastrointestinal symptoms and serum uric acid elevations (26). The overall adverse reactions were mild symptoms, but pregnant women should not be treated with favipiravir (25). In the presented study, serum uric acid levels were not evaluated but liver enzyme abnormalities were detected in parallel to the literature.

In a prospective, single-arm and multicenter study conducted in Italy with 63 patients with severe COVID-19, a decrease in CRP, ferritin and D-dimer levels was observed after tocilizumab treatment (27). In our study, when the laboratory values of the $3^{\text {rd }}$ day were examined, it was observed that the D-dimer level increased in patients who received only favipiravir treatment, while the level of D-dimer decreased in those who received favipiravir+tocilizumab treatment. In a study conducted with 23 patients who had severe COVID-19 and were hospitalized in ICU in Turkey, it was shown that CRP and ferritin values decreased while D-dimer values increased after tocilizumab treatment (27).

\section{Conclusion}

Favipiravir demonstrates a proper safety profile. However, its side effects including teratogenicity, hyperuricemia and QTc prolongation have not yet been adequately studied. It may be safe and tolerable in short-term use, but more evidence is needed to assess the longer-term effects of treatment.

\section{Ethics}

Ethics Committee Approval: The study was approved by the Ethics Committee of University of Health Sciences Turkey, İstanbul Göztepe Training and Research Hospital, Turkey with the decision number 2020/0243.

Informed Consent:The study was designed retrospective.

Peer-review: Externally peer-reviewed.

\section{Authorship Contributions}

Concept: H.Y., Desing: H.Y., Data Collection or Processing: H.Y., Analysis or Interpretation: H.Y., M.A., Drafting Manuscript: H.Y., A.E.G., Critical Revision of Manuscript: H.Y., A.E.G., Final Approval and Accountability: H.Y., A.E.G., M.A., Technical of Material Support: H.Y., A.E.G., M.A., Supervision: H.Y., A.E.G., M.A.

Conflict of Interest: No conflict of interest was declared by the authors.

Financial Disclosure: The authors declared that this study received no financial support.

\section{References}

1. Tsitoura E, Bibaki E, Bolaki M, Vasarmidi E, Trachalaki A, Symvoulakis EK, et al. Treatment strategies to fight the new coronavirus SARS-CoV: A challenge for a Rubik's Cube solver. Exp Ther Med 2020;20(1):147-150.

2. Tu YF, Chien CS, Yarmishyn AA, Lin YY, Luo YH, Lin YT, et al. A review of SARS-CoV-2 and the ongoing clinical trials. Int J Mol Sci 2020;21(7):2657.

3. Yousefi B, Valizadeh S, Ghaffari H, Vahedi A, Karbalaei M, Eslami M. A global treatments for coronaviruses including COVID-19. J Cell Physiol 2020;235(12):9133-9142.

4. Guan WJ, Ni ZY, Hu Y, Liang WH, Ou CQ, He JX, et al. Clinical characteristics of coronavirus disease 2019 in China. N Engl J Med 2020;382(18):1708-1720.

5. Matsushita K, Ding N, Kou M, Hu X, Chen M, Gao Y, et al. The relationship of COVID-19 severity with cardiovascular disease and its traditional risk factors: a systematic review and meta-analysis. Glob Heart 2020;15(1):64.

6. INSERM: Launch of a European clinical trial against COVID-19 (press release). Available from http:// https://www.ncbi.nlm.nih. gov/pmc/articles/PMC7281719/Accessed March 22, 2020. 
7. World Health Organization: Launch of SOLIDARITY trial (press release). Accessed March 18, 2020.

8. Remport A, Gerlei Z, Creprekal O, Wagner L, Foldes K, Marton A, et al. Guidance on the special care of liver or kidney transplant recipients diagnosed with Covid-19. Orv Hetil 2020;161(32):13101321.

9. Dong L, Hu S, Gao J. Discovering drugs to treat coronavirus disease 2019 (COVID-19) Drug Discov Ther 2020;14(1):58-60.

10. Delang L, Abdelnabi R, Neyts J. Favipiravir as a potential countermeasure against neglected and emerging RNA viruses. Antiviral Research 2018;153:85-94.

11. Shiraki K, Daikoku T. Favipiravir, an anti-influenza drug against life-threatening RNA virus infections. Pharmacol Ther 2020;209:107512.

12. Duan Y. Advance of promising targets and agents against COVID-19 in China. Drup Discov Today 2020;25(5):810-812.

13. Takahashi N, Abe R, Hattori N, Taniguchi T, Igari H, Nakada T. Clinical course of a critically ill patient with severe acute respiratory syndrome coronavirus 2 (SARS-CoV-2). J Artif Organs 2020;23(4):397-400.

14. Chen N, Zhou M, Dong X, Qu J, Gong F, Han Y, et al. Epidemiological and clinical characteristics of 99 cases of 2019 novel coronavirus pneumonia in Wuhan, China: A descriptive study. Lancet 2020;395(10223):507-513.

15. Chen C, Huang J, Cheng Z, Wu J, Chen S, Zhang Y, et al. Favipiravir versus arbidol for COVID-19: a randomized clinical trial. medRxiv. 2020.03.17.20037432 doi: 10.1101/2020.03.17.20037432

16. ClinicalTrials.gov. Various combination of protease inhibitors oseltamivir favipiravir hydroxychloroquine for treatment of COVID-19: a randomized control trial (THDMS-COVID-19). Available from: https://clinicaltrials.gov/ct2/show/NCT04303299. Accessed March 23, 2020.

17. ClinicalTrials.gov. Favipiravir combined with tocilizumab in the treatment of corona virus disease. Available from: https:// clinicaltrials.gov/ct2/show/NCT04310228.Accessed March 23, 2020.

18. Newswire PR: Sihuan pharmaceutical announces clinical research of favipiravir, co-developed with the Academy of Military Medical
Sciences of the People's Liberation Army, has commenced. Sihuan Pharmaceutical Holdings Group Ltd, 2020. Available from: https://en.prnasia.com/releases/apac/sihuan-pharmaceuticalannounces-clinical-research-of-favipiravir-co-developed-withthe-academy-of-military-medical-sciences-of-the-people-s-liberation-army-has-commenced-273880.shtml. Accessed March 26, 2020 .

19. Cai Q, Yang M, Liu D, Chen J, Shu D, Xia J, et al. Experimental treatment with favipiravir for COVID-19: an open-label control study. Engineering (Beijing) 2020;6(10):1192-1198.

20. Chinello P, Petrosillo N, Pittalis S, Biava G, Ippolito G, Nicastri E; INMI Ebola Team. QTc interval prolongation during favipiravir therapy in an Ebolavirus-infected patient. PLoS Negl Trop Dis 2017;11(12):e0006034. doi: 10.1371/journal.pntd.0006034.

21. Yenerçağ M, Arslan U, Doğduş M, Günal Ö, Öztürk ÇE, Aksan G, et al. Evaluation of electrocardiographic ventricular repolarization variables in patients with newly diagnosed COVID-19. J Electrocardiol 2020;62:5-9.

22. News. Last Accesed Date: 22.02.2020. Available from: http://www. szdsyy.com/News/0a6c1e58-e3d0-4cd1-867a-d5524bc59cd6. html. (Chinese).

23. Antonio R, Silvia M. Immunosuppression drug-related and clinical manifestation of coronavirus disease 2019: A therapeutical hypothesis. Am J Transplant 2020;20(7):1947-1948.

24. Guillen E, Pineiro GJ, Revuelta I, Rodriguez D, Bodro M, Moreno A, et al. Case report of COVID-19 in a kidney transplant recipient: does immunosuppression alter the clinical presentation? Am J Transplant 2020;20(7):1875-1878.

25. A Pharmacokinetics study of favipiravir in patients with severe influenza. Available from: https://clinicaltrials.gov/ct2/show/ NCT03394209. Accessed March 26, 2020.

26. Sciascia S, Apra F, Baffa A, Baldovino S, Boaro D, Boero R, et al. Pilot prospective open, single-arm multicentre study on off-label use of tocilizumab in severe patients with COVID-19. Clin Exp Rheumatol 2020;38(3):529-532.

27. Çiyilitepe F, Saraçoğlu A, Bilir Y, Akova Deniz E, Bombacı E, Saraçoğlu KT. The role of IL-6 receptor inhibitor treatment in critical patient monitoring with COVID-19. Signa Vitae 2021;17(3):174-180. 